\title{
STRUCTURAL BEHAVIOR OF METAKAOLIN INFUSED CONCRETE STRUCTURE
}

\author{
J. O. Akinyele ${ }^{1,}{ }^{*}$, S. O. Odunfa ${ }^{2}$, A. A. Famoye ${ }^{3}$ and S. I. Kuye ${ }^{4}$ \\ 1,2,3 Department of Civil EngineERing, Federal University of Agriculture, AbEokUta, OGUn STAte, NigERIA \\ 4 Dept. of Mechanical Engineering, Federal University of Agriculture, ABeokuta, OGUn State NigeriA \\ E-mail addresses:1 joakin777@yahoo.com, ${ }^{2}$ odunfaso@funaab.edu.ng,3biodunfamoye@gmail.com, \\ 4 kuyesi@funaab.edu.ng
}

\begin{abstract}
This work researched into the use of metakaolin as a partial substitute for cement in concrete, metakaolin was obtained by the calcination of kaolin clay to about $700{ }^{\circ} \mathrm{C}$ Cement was replaced with the metakaolin at $0,5,10,15,20,25,30$, and $35 \%$ at water cement ratio of 0.5 . Tests such as chemical analysis, compressive strength, flexural or modulus of rupture and bond strength were carried out on the concrete samples. Chemical analysis results showed that the metakaolin is a class " $N$ " pozzolan, while the mechanical test showed that the strength of concrete increased from 5\% to $20 \%$ replacement, and the strength peaked at $20 \%$, but decreased above this value; concrete made with metakaolin performed better than the control sample at all the percentage replacements used in this work.
\end{abstract}

Keywords: Metakaolin, Calcination, Pozzolan, Chemical test, Mechanical test

\section{INTRODUCTION}

The continuous increase in the cost of cement and the effect of air pollution being experienced during the production of cement has led to different research works that are currently being carried out all over the world for alternative materials to cement. Research has looked into the use of rice husk ash, corn cob ash, grand nut shell ash and fly ash as supplementary materials for partial replacement for cement in the construction industry. Recently, attentions have been turned to the use of other pozzolanic materials like clay, kaolin, industrial waste like slag, silica fume, etc.

This study has looked into the use of metakaolin, a product of the calcination of kaolin clay as a partial replacement of cement in concrete. Metakaolin is produced from heat treating (calcination) of Kaolin clay, one of the most abundant soil minerals formed from the chemical weathering of rocks (feldspar rocks) in hot moist climate [1]. Metakaolin is a highly reactive alumino silicate pozzolan that is rich in Silica and Alumina. These oxides combine with slake slime $\mathrm{Ca}(\mathrm{OH})_{2}$ in the presence of water (moisture) to form compounds that are virtually identical to the compounds in hydrated Portland cement [2].

Metakaolin has been widely studied for its highly pozzolanic properties. In fact metakaolin is considered to have twice the reactivity of most other pozzolans and is considered a very viable admixture; suggesting that metakaolin could be used as supplementary cementitious materials to produce materials with higher strength, denser microstructure, lower porosity, higher resistance to ions with improved durability properties [3].

In a recent work, [4] investigated the effect of metakaolin on concrete properties. The work deals more specifically on the comparison of a locally produced metakaolin from Greek kaolin to a commercial one with the aim at the exploitation of Greek kaolin in concrete technology. The result obtained from the research showed that the locally produced metakaolin as well as the commercial one showed similar behavior in the area of strength development and durability.

[5], reported that the maximum increase in compressive strength of metakaolin blended cement concrete was achieved at 15\% replacement level and flexural strength measured by third point loading increased by $20-40 \%$ at $10 \%$ replacement of cement with metakaolin.

[6], reported that the tensile strength of concrete increased by $28 \%$ at $15 \%$ replacement of cement with metakaolin at 28 days. Also, at $10 \%$ and $15 \%$ replacement of cement with metakaolin, the28-day bond strength increased by $32 \%$ and $38 \%$ respectively.

Kaolin is one of the industrial minerals that can be found in commercial quantities in Nigeria. It was estimated by Raw Material Research Council of Nigeria (RMRDC) that the country has a reserve of about (3) three billion metric tonnes of kaolin deposit scattered in difference parts of the country which includes Ogun, Edo, Plateau, Nassarawa, Katsina, Ekiti, Kogi, Abia, Kano, Niger, 
Bauchi, Sokoto, Kaduna, Oyo, Delta, and Borno states. The market for kaolin is large, sustainable and expanding because of numerous applications of the products. Good prospects exist in kaolin mining and prospecting in Nigeria [7].

The study was aimed at localizing the use of kaolin (metakaolin) as it has being done in other parts of the world as a material for partial replacement of cement in concrete production. Most of these kaolin deposits are been underutilized by the authority, while there are a lot of illegal mining activities going on in the area that has this precious material. With the present campaign of the government in diversifying the economy, it is the believe of the research team that our locally available raw material like kaolin that is present in about 17 states of the federation can improve the economy of the country.

\section{MATERIAL AND METHODS}

\subsection{Materials}

Metakaolin, a supplementary cementitious material used for the work, was obtained in sufficient quantities from calcination of locally sourced kaolin clay. Samples of Kaolin clay were collected from one of the kaolin deposit sites (Isan-Ekiti) in the south western part of Nigeria.

\subsection{Production of metakaolin}

The Kaolin sample shown in Plate 1 was ground to powder using a grinding machine. The kaolin powder was fired (calcined) in the Raw Material laboratory of the Federal Institute of Industrial Research (FIIRO) Lagos, Nigeria, at controlled temperature of $700^{\circ} \mathrm{C}$ in an electrically fired Kiln (furnace) and soaked (maintained) for one hour, the furnace (kiln) was switched off and the resulted metakaolin was brought out and allowed to cool at room temperature, this produced a highly reactive alumino-silicate pozzolanic material rich in silica and alumina. After cooling, the resultant metakaolin powder (Plate 2) was further ground, and sieved, passed through $150 \mu \mathrm{m}$ and retained in $100 \mu \mathrm{m}$ sieve size and sample of it was taken for chemical analysis.

\subsection{Chemical analysis of Metakaolin Powder}

Chemical analysis was conducted on the sample of the Metakaolin in order to determine the chemical contents. About 3 gm of metakaolin powder was weighed; $30 \mathrm{ml}$ of Nitric acid $\left(\mathrm{HNO}_{3}\right)$ and hydrochloric acid (HCL) in ratio of 2:1 was added and digested in a muffle furnace at $150^{\circ} \mathrm{C}$ for 30 minutes. Additional $20 \mathrm{ml}$ of HCL was added and the temperature was increased to $230^{\circ} \mathrm{C}$ and digested for one and half hours and allowed to cool down at room temperature, $20 \mathrm{ml}$ of distilled water was added to the digested sample and washed into $50 \mathrm{ml}$ standard volumetric flask. Compounds like calcium (Ca), magnesium (Mg), silicon ( $\mathrm{Si}$ ), aluminum (Al) and ferrous iron (Fe) oxides were determined on an atomic absorption spectrum photometer (Plate 3) which uses a light beam to excite these ground state atoms absorbed in the flame and relate it to concentration of standard sample measured calorimetrically, while oxides of sodium $(\mathrm{Na})$ and potassium(K) were determined on a Flame Photo-Spectrometer(Plate 4). As the sample was raised to a high temperature causing emission of light, each element has a characteristic set of wave-length and the intensity of the emission was used to calculate the concentration according to their presence on the Periodic Table.

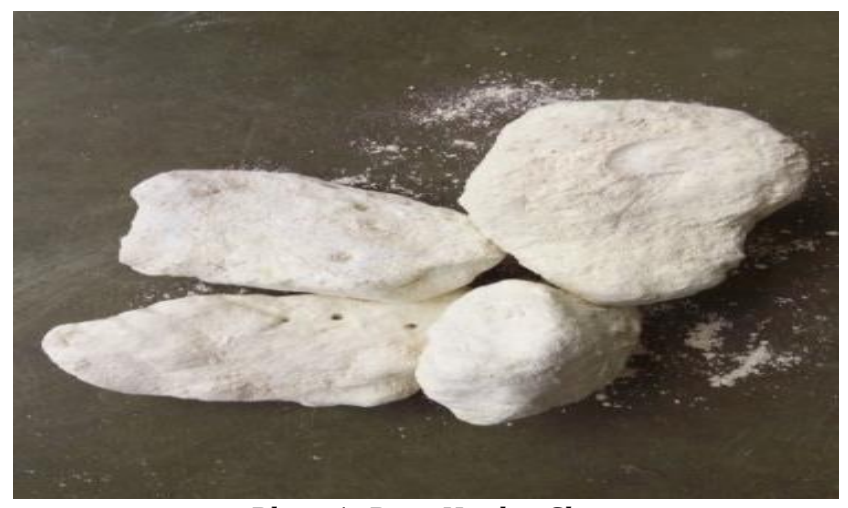

Plate 1: Raw Kaolin Clay.

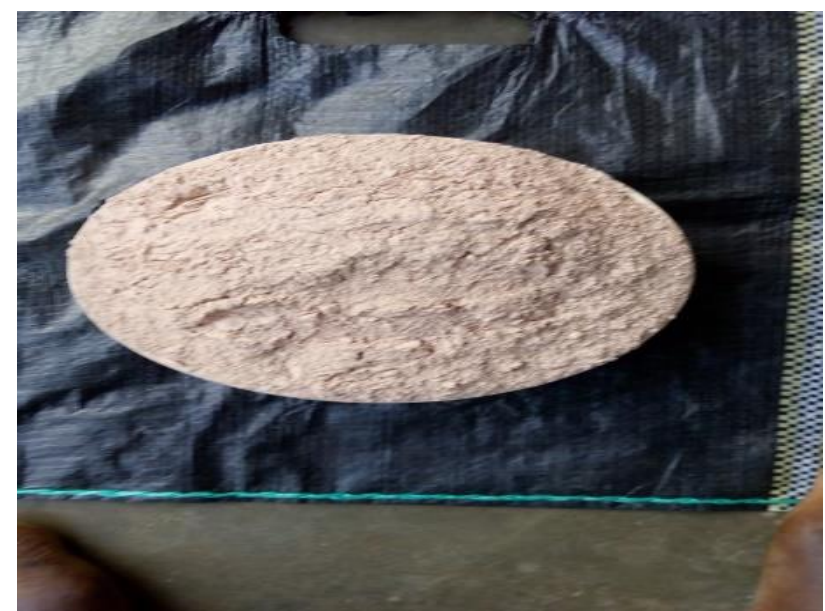

Plate 2: Metakaolin powder.

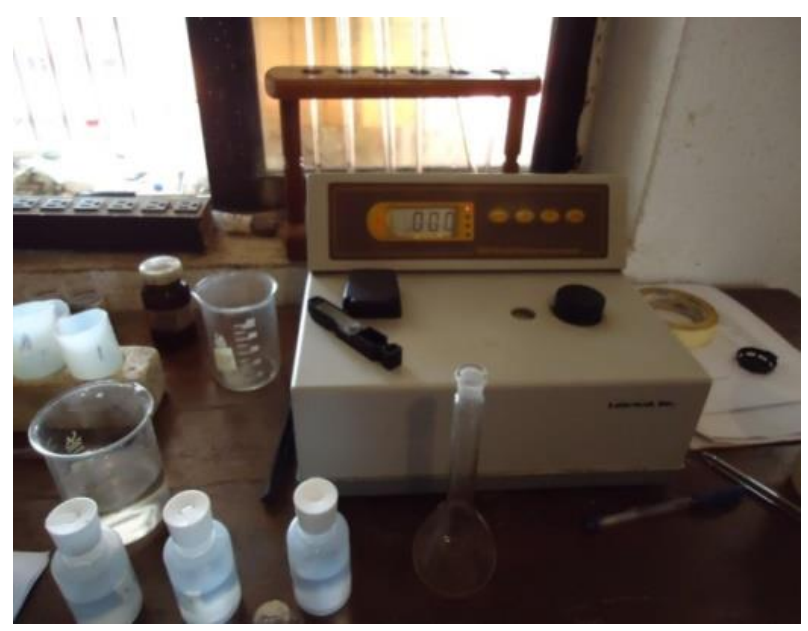

Plate 3: Atomic spectrum photometer. 


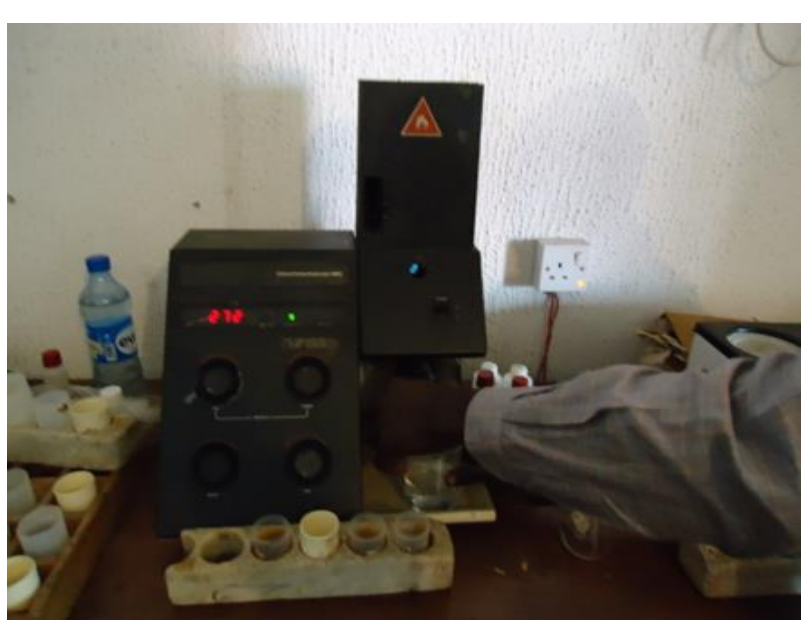

Plate 4: Flame Photo Spectrometer

\subsection{Preparation of Concrete Samples.}

The cement used in the production of all the concrete specimens for this work was Ordinary Portland Cement in line with [8] as cementitious binder, with a Specific gravity of 3.12. The fine aggregate that was used for this work was sourced form Ogun River, clean, well graded and free from organic materials passing through 4.75 $\mathrm{mm}$ sieve and with specific gravity of 2.65. Crushed rock, angular in shape well graded, clean, free from surface dirt and obtained from a quarry passing through $14 \mathrm{~mm}$ sieve with Specific gravity of 2.8 was used as coarse aggregate for this work.

Steel moulds of size $150 \mathrm{~mm}$ x $150 \mathrm{~mm}$ x $150 \mathrm{~mm}$ cube and steel cylindrical moulds of size $150 \mathrm{~mm}$ diameter by $300 \mathrm{~mm}$ depth were used for the casting of concrete cubes and the cylindrical concrete specimens respectfully. Plywood formwork of dimension $150 \times 150$ $\times 500 \mathrm{~mm}$ was partitioned for the casting of the concrete beam specimens.

Concrete mix ratios were designated as $\mathrm{C}_{0}, \mathrm{C}_{10}, \mathrm{C}_{15}, \mathrm{C}_{20}$, $\mathrm{C}_{25}, \mathrm{C} 30$, and $\mathrm{C}_{35}$ for $0,10,15,20,25,30$ and $35 \%$ metakaolin cement replacement respectively, with curing ages of $7,14,28$ and 90 days with water- cement ratio of 0.50 was used in the production of various concrete type specimens and in according to [9].Batching by weight was used and slump test in line with the provisions of [10] was carried out to measure the workability of all concrete mixtures. The concrete design strength of $20 \mathrm{~N} / \mathrm{mm}^{2}$ at 28 days curing age was targeted for the control sample.

A total of 96concrete cubes were used, three concrete cubes each as controlled specimens were crushed to obtain the average compressive strength of various mixes in line with the provisions of [9]. The cast cubes were used to determine the optimum percentage replacement of cement with metakaolin.

A total of 48 reinforced concrete beams with $12 \mathrm{~mm}$ diameter high yield steel reinforcing bars were cast according to the provisions of [9] for flexural tests after 28 and 90 days, to determine the flexural characteristic of metakaolin-cement concrete for structural usage.

$12 \mathrm{~mm}$ diameter high yield steel reinforcement bars were embedded in a total number of 48 concrete cubes for pull-out test for bonding strength after 28 and 90 days to investigate the bond behavior between concrete and reinforcing bar.

All specimens were de-moulded after 24 hours and transferred into a large curing tank containing clean water where they were stored till the respective testing ages $(7,14,28$ and 90 days) at curing temperature of 22 $\pm 1^{\circ} \mathrm{C}$.

\subsection{Flexural Strength Test}

The beam specimens at the curing ages of 28 and 90 days were tested using a third point loading method. The apparatus used for this flexural strength test include a hand operated testing machine called Loading Cell Equipment,(Plate 5).The loading cell machine is made up of a power pump and a hydraulic power jack upon which a gauge is mounted, the machine provided continuous (uniform rate) loading of $5 \mathrm{kN}$ per seconds/stroke to breaking (failure) point. The applied load by the jack per stroke was read on the gauge and recorded. Also, a dial gauge with sensitivity of $0.01 \mathrm{~mm}$ precision was mounted centrally under the beam with tip touching the beam so as to measure the deflection of the beam due to the applied load, as the load was applied gradually, the stiff resistance put up by the concrete due to compression and tensile reinforcement caused the deflection of the beam to be read through the dial gauge per load applied and recorded.

The deflection and the applied load were read continuously until the failure (yield) load was reached. The point load at which the application of the hydraulic jack became stable but the dial gauge continuously increases is known as the yield or failure load. The crack width corresponding to this failure load was measured and recorded as the failure crack. The corresponding strength to the failure load was calculated and recorded as the fractured strength (Modulus of Rupture). Since the fracture occurred in the tension zone within the middle third of the span length, the Modulus of rupture $\left(\mathrm{N} / \mathrm{mm}^{2}\right)$ for the test was calculated using the formula

$$
\text { Modulus of rupture, } R=\frac{P l}{b d^{2}}
$$

Where: $P$ is the Maximum applied load at fracture, $b$ is the Width of the specimen $(150 \mathrm{~mm}), d$ is the Depth of the specimen $(150 \mathrm{~mm})$ and $I$ is the Span length $(500$ $\mathrm{mm}$ ).

The crack widths were experimentally measured at failure loads and were also analyzed theoretically, the crack widths corresponding to the failure loads were 
determined by analysis of section in accordance with [11].

\subsection{Bond Strength Test}

A total of forty eight $150 \mathrm{~mm}$ concrete cubes were used for this test, $12 \mathrm{~mm}$ diameter rods were cut into short pieces of $250 \mathrm{~mm}$ long and placed centrally in the molds prepared for this purpose after it had been cleaned and oiled, with the rods extending $50 \mathrm{~mm}$ outside the mold both ways.

The pull out test machine was a load rig on which load cell equipment was mounted (Plate 6), the set-up of the test apparatus and the load arrangement consist of a hydraulic jack upon which a load gauge was fixed to measure the load applied per stroke of the jack. At the unloaded end, a dial gauge was mounted with the accuracy of $0.01 \mathrm{~mm}$ to measure the slip of the steel reinforcement.

The load was applied at a loading rate of $5 \mathrm{kN}$ per second by the hydraulic jack to failure (pull out or splitting). The applied force due to load was transferred through the rod to the concrete to break the adhesive resistance and the grip between the rod and concrete. A dial gauge mounted underneath the cube with tip of the gauge touching the rod allowed the measurement and recordings of the slip distance as the load forced the rod to slip through the concrete to failure.

Three specimens were tested for each batch, the record of failure load and slip distance were recorded. The average of the loads at which the specimen failed was determined and used for calculating the bond strength. The bond strength (bond stress) was calculated using the formula:

$$
\text { Bond Strength }=\frac{P}{l \pi \varnothing}
$$

Where $P$ is the Failure load (ultimate load) KN, $I$ is the embedded length $(150 \mathrm{~mm})$, and $\varnothing$ is the Steel reinforcement bar diameter $(12 \mathrm{~mm})$.

\section{RESULTS AND DISCUSSIONS}

\subsection{Chemical Analysis Results}

The chemical composition of Metakaolin as shown in Table 1 reflects a Silicon dioxide content of $52.72 \%$ by mass which is greater than [12] minimum requirement of $25 \%$ by mass and a combined Silicon dioxide, Iron oxide and Aluminum oxide $\left(\mathrm{SiO}_{2}+\mathrm{Fe}_{2} \mathrm{O}_{3}+\mathrm{Al}_{2} \mathrm{O}_{3}\right)$ content of $95.64 \%$ which is well above the code [13] requirement of $70 \%$ minimum for a pozzolan. The results also revealed that the percentage of oxides of iron, aluminum, silicon for both kaolin and metakaolin are very close, when compared to that of cement, but the loss of ignition of kaolin is higher at 10.17, while that of metakaolin and cement are close at 1.33 and 3.12 respectively.

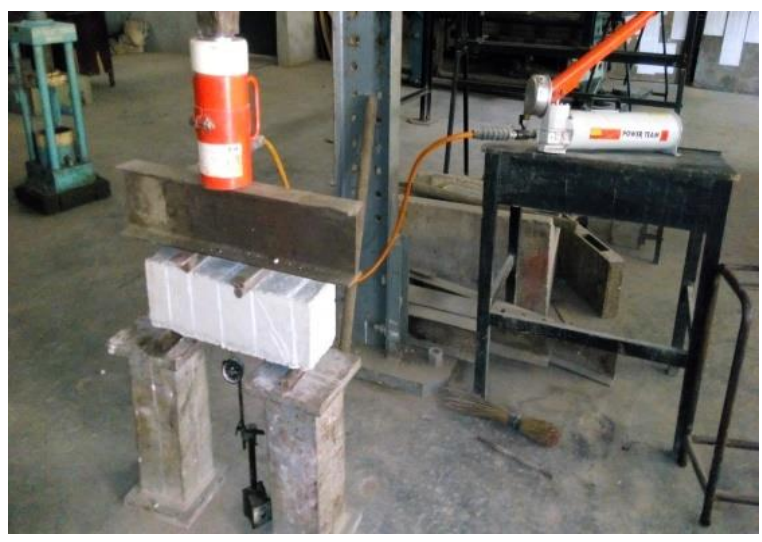

Plate 5: Flexural strength test set up.

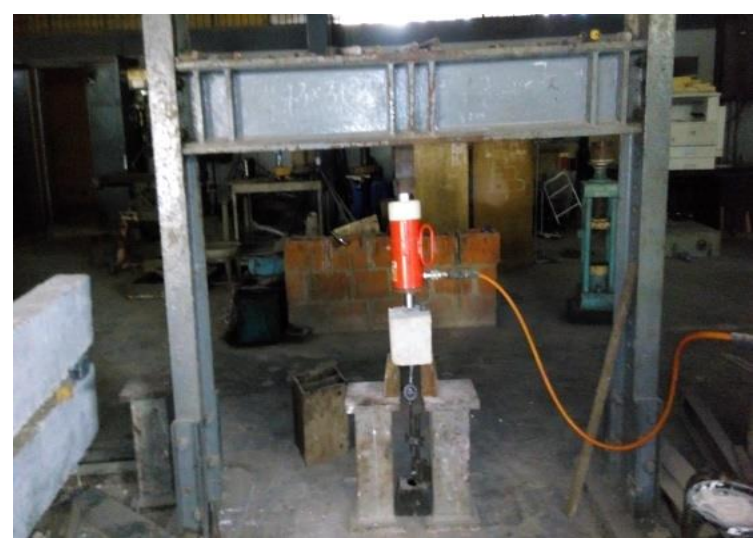

Plate 6: Pull out test set up

The low calcium oxide, and very high oxide of Silicon, and aluminum in both kaolin and metakaolin did not encourage a complete cementitious characteristics for this materials when compared with cement, hence both materials are classified as class "N"pozzolans, which are naturally occurring and are very good pozzolan.

Table 1: Chemical analysis results

\begin{tabular}{cccc}
\hline $\begin{array}{c}\text { Chemical } \\
\text { Content }\end{array}$ & $\begin{array}{c}\text { Kaolin } \\
\%\end{array}$ & $\begin{array}{c}\text { Metakaolin } \\
\%\end{array}$ & $\begin{array}{c}\text { Cement } \\
\%\end{array}$ \\
\hline $\mathrm{SiO}_{2}$ & 51.25 & 52.72 & 21.55 \\
$\mathrm{Al}_{2} \mathrm{O}_{3}$ & 40.70 & 41.18 & 5.64 \\
$\mathrm{Fe}_{2} \mathrm{O}_{3}$ & 1.18 & 1.74 & 3.16 \\
$\mathrm{CaO}$ & 0.32 & 0.20 & 63.61 \\
$\mathrm{MgO}$ & 0.28 & 0.10 & 4.56 \\
$\mathrm{Na}_{2} \mathrm{O}$ & 0.16 & 0.06 & 0.51 \\
$\mathrm{~K}_{2} \mathrm{O}$ & 0.20 & 0.18 & 0.08 \\
$\mathrm{LO}_{1}$ & 10.17 & 1.33 & 3.12 \\
\hline
\end{tabular}

\subsection{Compressive Strength}

The result of the compressive strength test carried out on $150 \mathrm{~mm}$ concrete cubes at 7, 14, 28 and 90 days are shown in Figure 1. There was significant increase in compressive strength of all concrete samples when compared to the control. Specifically, it was discovered from the result of metakaolin replaced samples $\left(\mathrm{C}_{5}-\mathrm{C}_{30}\right)$ that the compressive strength at 28 days and 90 days increased within the range of $12.40 \%$ to $36.58 \%$ and 
$9.22 \%$ to $42.68 \%$ respectively. The compressive strength of $\mathrm{C}_{20}$ sample at 28 days was $33.38 \mathrm{~N} / \mathrm{mm}^{2}$ compared to $24.44 \mathrm{~N} / \mathrm{mm}^{2}$ of $\mathrm{C}_{0} ; 36.84 \mathrm{~N} / \mathrm{mm}^{2}$ and 25.82 $\mathrm{N} / \mathrm{mm}^{2}$ at 90 days respectively, there was $36.58 \%$ and $42.68 \%$ increment at 28 days and 90 days for $\mathrm{C}_{20}$ when compared with $\mathrm{C}_{0}$ sample. The result obtained here showed that the maximum strength was achieved at 20 $\%$ replacement for all the test ages. The compressive strength result is in agreement with what was reported by [14], who tested concrete at a range of $5 \%$ to $30 \%$ metakaolin replacement produced at 0.40 water-cement ratio from one to 90 days and found that metakaolin produced significant (15\% to 50\%) compressive strength increase in concrete strength compared to control concrete. The increase in the strength of concrete mix with metakaolin can be attributed to the reactions between the oxides of Silicon, Aluminum, Ferrous iron and calcium in the cement and pozzolanic metakaolin, both materials complemented each other by contributing oxides of the mentioned metals in substantial quantity to the concrete, for the $25 \%$ to $35 \%$ metakaolin replacement in cement concrete, the amount of metakaolinite are probably too high and in excess of the quantity of the produced calcium hydroxide from the hydration of cement. This action therefore produces an immediate dilution effect such that the water-cememt ratio is reduced. Concrete strength therefore also reduced in approximation to the level of replacement, the implication of this is that care should be taken so that the replacement of cement by metakaolin in concrete should not exceed the threshold of $20 \%$. [15] reported that three elementary factors influenced the contributions that metakaolin made to strength when it partially replaced cement in concrete, one of them being filler effect which resulted in efficient paste packing and dense filling capacity at the aggregate / paste interface and therefore enhanced the density of the metakaolin concrete.

\subsection{Flexural Strength}

The results of the Flexural strength characteristics of concrete at 28 and 90 days of the metakaolincement concrete are shown in Figure 2. The result indicated increment on the various flexural strength characteristics of concrete as metakaolin was introduced. The higher strengths recorded all through the test was as result of the reinforcement in the beams. The flexural strength results showed that the strength behavior of metakaolin inclusion in concrete is significantly superior to the concrete that use only Portland cement as binder. The flexural strength of concrete with $20 \%$ replacement of cement with metakaolin at 28 and 90 days stood at 19.24 and $21.46 \mathrm{~N} / \mathrm{mm}^{2}$ compared with 14.10 and 15.84
$\mathrm{N} / \mathrm{mm}^{2}$ of the control respectively. However, it was noticed that at further introduction of metakaolin beyond $20 \%$, the flexural strength characteristics began to drop. Flexural strength (modulus of rupture) is essential to estimate the load carrying capacity of beams at which the concrete members may crack; this test is useful in the design of pavement slab and airfield runways [16].

The resistance of the reinforced concrete beam to applied load causes deflection, cracking and results in failure of the beam. Cracks are harmless unless the width becomes excessive that the appearance and durability suffer as reinforcement is exposed to corrosion [11]. The ductility of the reinforced concrete structure is also of paramount importance because any member should be capable of undergoing deflection at near maximum load carrying capacity before failure [17]. Deflection of reinforced concrete beams should satisfy the resistance of that member to applied load so that it will not affect the appearance and safety criteria of the structure [11].

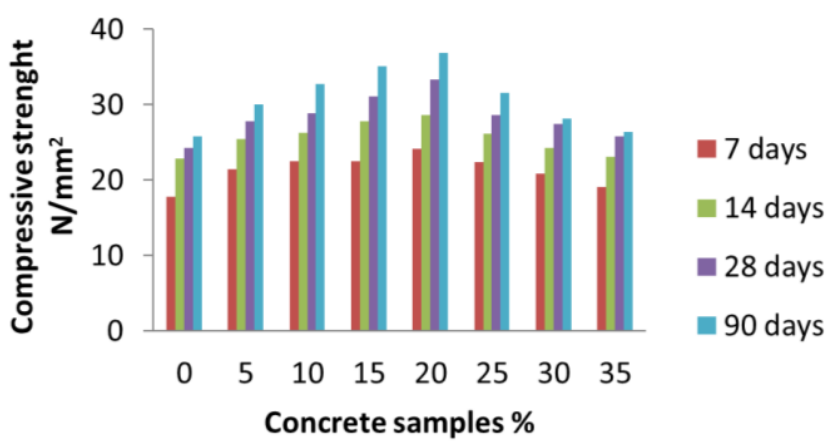

Figure 1: Compressive strength test result

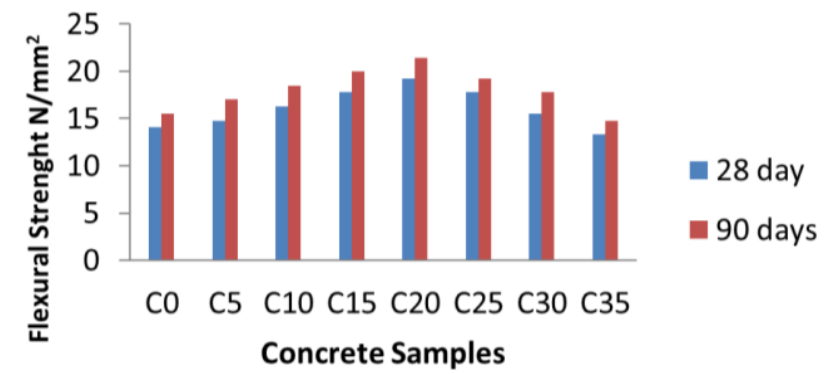

Figure 2: Flexural strength results of samples.

The resulting cracks from all the samples were from the supports to the point load area denoting shear failure at the support. The deflections, theoretical and experimental crack widths were recorded in Tables 1 and 2 . In the $\mathrm{C}_{0}$ sample, the failure load was $95 \mathrm{kN}$ and the deflection $6.60 \mathrm{~mm}$ resulting in $0.05 \mathrm{~mm}$ theoretical calculated crack width and the average experimental crack width of $0.80 \mathrm{~mm}$, compared to $\mathrm{C}_{10}$ sample with failure load of $110 \mathrm{kN}$, deflection of $8.28 \mathrm{~mm}$ and theoretical crack width of $0.065 \mathrm{~mm}$ and the average experimental crack width of $1.10 \mathrm{~mm}$. But as the metakaolin concentration increased the failure load increased, deflection increased and crack width widened 
exhibiting high resistance to the applied load confirming high strength in the metakaolin concrete up to $20 \%$ replacement, beyond this point, the failure load started to decrease with the deflection. At 25\% replacement, the failure load was $120 \mathrm{KN}$ and deflection $10.83 \mathrm{~mm}$ resulting in the average experimental crack width of 1.8 $\mathrm{mm}$ and theoretical crack width of $0.07 \mathrm{~mm}$. While at $35 \%$ replacement, the failure load decreased to $90 \mathrm{kN}$ with the deflection of $9.65 \mathrm{~mm}$ and experimental crack width of $2.60 \mathrm{~mm}$ with theoretical crack width of 0.05 mm.

The failure loads and deflections in the $\mathrm{C}_{20}$ sample in cement concrete beams stood at $130 \mathrm{kN}$ and $145 \mathrm{kN}$ with $12.89 \mathrm{~mm}$ and $15.90 \mathrm{~mm}$ deflections at 28 and 90 days respectively, higher than the control beam sample. The results generally showed that reinforced beam samples containing metakaolin sustained higher loads and resisted more deflections before collapse than the control beam; the higher deflection gives ample warning of imminent collapse.

[18]Recommends that the design crack width for serviceability requirements in the structural concrete elements should not lead to spoil appearance, steel corrosion, loss of the performance of the structure and the design calculated maximum crack width should not exceed $0.30 \mathrm{~mm}$ [19]. The result further showed that metakaolin blended reinforced concrete beams has better structural characteristics and higher ductility when compared to the control beam.

Table 1: Deflection and Crack width results at 28 day

\begin{tabular}{ccccc}
\hline Samples & $\begin{array}{c}\text { Failure } \\
\text { load } \\
(\mathrm{kN})\end{array}$ & $\begin{array}{c}\text { Deflection } \\
\text { at failure } \\
(\mathrm{mm})\end{array}$ & $\begin{array}{c}\text { Theoretical } \\
\text { crack } \\
\text { width(mm) }\end{array}$ & $\begin{array}{c}\text { Experimental } \\
\text { crack width } \\
(\mathrm{mm})\end{array}$ \\
\hline $\mathrm{C}_{0}$ & 95 & 6.60 & 0.055 & 1.20 \\
$\mathrm{C}_{5}$ & 100 & 7.35 & 0.060 & 1.40 \\
$\mathrm{C}_{10}$ & 110 & 8.28 & 0.065 & 1.40 \\
$\mathrm{C}_{15}$ & 120 & 10.58 & 0.070 & 1.50 \\
$\mathrm{C}_{20}$ & 130 & 10.91 & 0.075 & 1.60 \\
$\mathrm{C}_{25}$ & 120 & 10.83 & 0.070 & 1.80 \\
$\mathrm{C}_{30}$ & 105 & 10.24 & 0.060 & 2.20 \\
$\mathrm{C}_{35}$ & 90 & 9.65 & 0.050 & 2.60 \\
\hline
\end{tabular}

Table 2: Deflection and Crack width at 90 days

\begin{tabular}{ccccc}
\hline Samples & $\begin{array}{c}\text { Failure } \\
\text { load } \\
\mathrm{kN}\end{array}$ & $\begin{array}{c}\text { Deflection } \\
\text { at failure } \\
(\mathrm{mm})\end{array}$ & $\begin{array}{c}\text { Theoretical } \\
\text { crack } \\
\text { width } \\
(\mathrm{mm})\end{array}$ & $\begin{array}{c}\text { Experimental } \\
\text { crack width } \\
(\mathrm{mm})\end{array}$ \\
\hline $\mathrm{C}_{0}$ & 105 & 9.4 & 0.060 & 1.10 \\
$\mathrm{C}_{5}$ & 115 & 11.43 & 0.065 & 1.50 \\
$\mathrm{C}_{10}$ & 125 & 13.12 & 0.075 & 1.60 \\
$\mathrm{C}_{15}$ & 135 & 13.87 & 0.080 & 1.60 \\
$\mathrm{C}_{20}$ & 145 & 14.98 & 0.085 & 1.80 \\
$\mathrm{C}_{25}$ & 130 & 13.46 & 0.075 & 2.20 \\
$\mathrm{C}_{30}$ & 120 & 14.31 & 0.070 & 2.60 \\
$\mathrm{C}_{35}$ & 100 & 12.95 & 0.060 & 3.10 \\
\hline
\end{tabular}

\subsection{Bond Strength}

The result of the pullout test for bond strength on reinforced concrete cubes are presented in Tables 3 and 4. The bond strength results generally showed that the addition of metakaolin increased the bond strength of concrete mixtures. The strength attained by metakaolin concrete with $5 \%$ and up to $30 \%$ replacement at 28 and 90 days wasin the range of $9.82 \%$ to $49.66 \%$ and $8.29 \%$ to $49.99 \%$ respectively above the control concrete.

However, the $\mathrm{C}_{20}$ sample recorded the maximum bond strength at the test ages with $13.26 \mathrm{~N} / \mathrm{mm}^{2}$ and 9.76 $\mathrm{N} / \mathrm{mm}^{2}$ at 28days and 90 days respectively, while the control has $10.61 \mathrm{~N} / \mathrm{mm}^{2}$ and $15.91 \mathrm{~N} / \mathrm{mm}^{2}$ at 28 and 90 days respectively.[6]Reported the increment of $32 \%$ and $38 \%$ in bond strength of concrete of $10 \%$ and $15 \%$ metakaolin replacement in concrete respectively at 28 days curing age.

Three types of failure were observed during the test, splitting failure, pullout failure and steel rupture failure (SRF), and two types of failure types are shown in Plates7 and 8 . Twenty eight specimens failed by splitting failure which was the predominant type of failure witnessed, 16 failed by pullout failure and 8 failed by steel rupture failure (which is a steel bar yielding failure which happened when the stress in the bar reached yield point and bent).
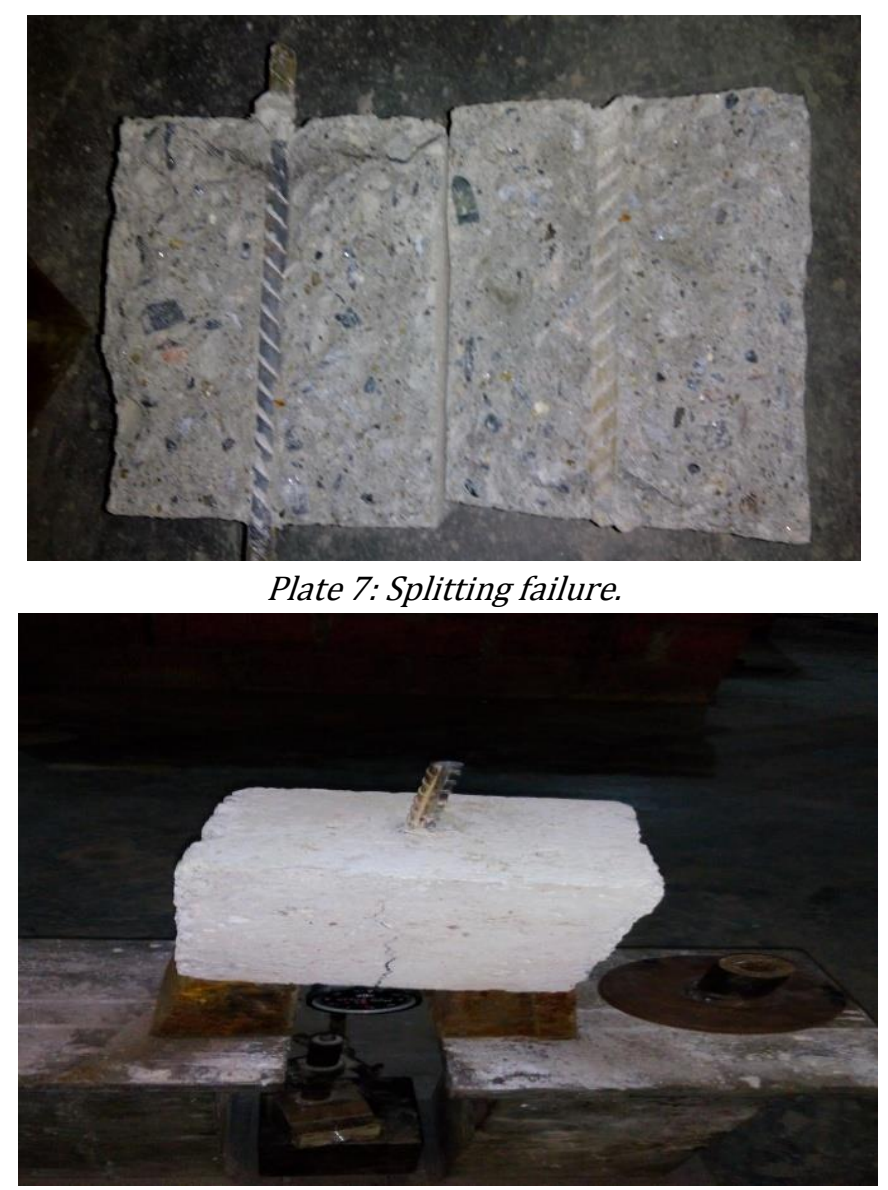

Plate 8: Pull out failure 
During the pull out test, compressive stresses are developed within the concrete, these stresses are products of reactive forces that are trying to hold the reinforcing steel bar from slipping away from the concrete, but when more greater pull out forces are applied to the steel rod, the compressive stress developed by the concrete surrounding the steel rod will give way, hence failure will occur by any of the three types of failure mentioned above. The principle here is like the type experienced in prestressed concrete beam, when tension from the tendon is transferred to the surrounding concrete during the prestressing activity. The reason for the high bond stress for samples $C_{5}$ to $C_{20}$ can be attributed to the presence of high oxides of silicon, aluminum, and calcium in the metakaolin which gave it the pozzolanic properties, and allowed very strong bonds to be formed within the aggregate interface and cement material in the concrete.

[20]reported that the bond strength of reinforced concrete structural elements depends on the bond between concrete and reinforcement to ensure effective transfer of stress from steel reinforcement to the surrounding concrete and that the bond is usually high at later age because the compressive strength of concrete and the grip effect on reinforcement increase with age.

Table 3: Test Result for Pullout Specimens (28 Days)

\begin{tabular}{cccc}
\hline Samples & $\begin{array}{c}\text { Failure } \\
\text { Load } \\
\text { KN }\end{array}$ & $\begin{array}{c}\text { Maximum } \\
\text { Slip } \\
(\mathrm{mm})\end{array}$ & $\begin{array}{c}\text { Bond Stress } \\
\text { MPA } \\
\left(\mathrm{N} / \mathrm{mm}^{2}\right)\end{array}$ \\
\hline $\mathrm{C}_{0}$ & 50 & 2.48 & 8.84 \\
$\mathrm{C}_{5}$ & 55 & 3.46 & 9.73 \\
$\mathrm{C}_{10}$ & 65 & 4.38 & 11.49 \\
$\mathrm{C}_{15}$ & 70 & 4.06 & 12.38 \\
$\mathrm{C}_{20}$ & 75 & 4.45 & 13.26 \\
$\mathrm{C}_{25}$ & 60 & 4.15 & 10.61 \\
$\mathrm{C}_{30}$ & 55 & 3.79 & 9.73 \\
$\mathrm{C}_{35}$ & 45 & 3.60 & 7.96 \\
\hline
\end{tabular}

Tables 4 : Test Results of Pull Out Specimens (90 Days)

\begin{tabular}{cccc}
\hline Samples & $\begin{array}{c}\text { Failure } \\
\text { Load kN }\end{array}$ & $\begin{array}{c}\text { Maximum } \\
\text { slip }[\mathrm{mm}]\end{array}$ & $\begin{array}{c}\text { Bond stress } \\
{\left[\mathrm{N} / \mathrm{mm}^{2}\right]}\end{array}$ \\
\hline $\mathrm{C}_{0}$ & 60 & 3.54 & 10.61 \\
$\mathrm{C}_{5}$ & 65 & 4.36 & 11.49 \\
$\mathrm{C}_{10}$ & 75 & 4.66 & 13.26 \\
$\mathrm{C}_{15}$ & 80 & 5.16 & 14.14 \\
$\mathrm{C}_{20}$ & 90 & 5.50 & 15.91 \\
$\mathrm{C}_{25}$ & 75 & 5.14 & 13.26 \\
$\mathrm{C}_{30}$ & 65 & 4.61 & 11.49 \\
$\mathrm{C}_{35}$ & 50 & 3.89 & 8.84 \\
\hline
\end{tabular}

\section{CONCLUSION}

This work has looked into some of the structural properties of concrete made from the partial replacement of cement in concrete, the chemical analysis revealed that metakaolin samples used in this study is a very good pozzolan and classified according to [13] as class "N".

The compressive strength, the flexural strength and the bond strength tests all showed that partial replacement of cement with metakaolin in concrete up to $20 \%$ gave an increase in strength and good results, when compared with the control sample, this is a very encouraging result as the use of metakaolin as supplements in concrete up to $20 \%$ will reduce the cost of cement and the negative environmental pollution being experienced as a result of cement production. The abundant metakaolin deposits in Nigeria can be effectively utilized in the construction industry for making concrete structures that contains partial replacement of cement.

\section{REFERENCES}

[1] iljana, R. I. Mitrovic, L. Milicic, R."Thermal Treatment of Kaolin Clay to Obtain Metakaolin". Hem. Ind. 64 (4) pp 351-358, 2010.

[2] Fernandez, R., Martirenal, F. Scrivener, K. L."The Origin of the Pozzolanic Activity of Clay Minerals: A Comparison between Kaolinite Illite and Mortimorillonite". Cement and Concrete Research. 41: pp 113-122, 2011.

[3] Poon, C. S., Azhar, S., Anson, M. and Wong, Y. L. "Comparison of the Strength and Durability Performance of Normal and High-Strength Pozzolanic Concrete at Elevated Temperatures". Journal on Cement and Concrete Research,vol. 31:1291-1300, 2001.

[4] Badogiannis, E., Tsivilis S., Papadakis V, Chaniotakis E. "The Effect of Metakaolin on Concrete Properties". International Congress on Challenges of Concrete Construction In Innovation and Development In Concrete Materials and Construction. Sept. Edition, pp. 81-89, 2002.

[5] Justice, J. M. and Kurtis, K. E. "Influence of metakaolin surface area on properties of cementbased materials". Journal of Materials in Civil Engineering. 19 (9): pp 762-771, 2007.

[6] Quian, X. and Li, Z. 2001. "The relationship between stress and strain for high performance concrete with Metakaolin". Cement Concrete.es. 31(11): pp 1607-1611, 2001.

[7] Raw Materials Research and Development Council (RMRDC) Technical Brief on Minerals in Nigeria (Kaolin) November. pp 6-21, 2008.

[8] British Standard Institution. BS 12: Specification for Portland Cements. BSI. London. 1991.

[9] British Standard Institute. BS EN 12390: 3-6. Testing of Hardened Concrete, Making and curing Specimens for Strength, Shape Dimension and 
Other Requirement for Specimens and Mould. BSI, London. 2009.

[10] British Standard Institute. BS 1881-2 Method of Making Test Cubes for Fresh Concrete. BSI, London. 1996.

[11] Mosley B. Bungey J. and Hulse R. Reinforced Concrete Design. Palgrade Macmillan Hampshire. New York. 2007.

[12] British Standard Institution. BS EN 197-1.Cement Composition Specifications. 2000

[13] American Society for Testing and Materials (ASTMC 618- 12). "Specification for Raw or Calcined Natural Pozzolans for use as a Mineral Admixture in Portland Cement Concrete". 2008.

[14] Wild, S., Khatib, J. M. and Jones, A. "Relative strength, pozzolanic activity and cement hydration in superplasticized Metakaolin concrete". Cement ConcreteResearch 26(10): 1537- 1544, 1996.

[15] Sabir, B.B., Wild, S. and Bai, J. "Metakaolin and calcined clays as pozzolona for concrete: A review". Cement Concrete Composites. 23: 441454, 2001.

[16] Steven, H. K. Beatrix, K. and Willian, C. P. “Design and Control of Concrete Mixture , IS001. Michigan". Journal of the American Concrete Institute, 8(10), pp. 30-36, 2011.

[17] Teo, D. C. L, Mannan M. A, Kurian J. V. "Flexural Behavior of Reinforced Concrete Beams made with Oil Palm Shell (OPC)". Journal of Advanced Concrete Technology, 4: 459-468, 2006.

[18] British Standard Institution. BS 8110, Part 1.The Structural Use of Concrete, Design, Materials and Workmanship. BSI, London. 1997.

[19] Said, M., Mohie S. S., Amal S. H. "Crack width evaluation for flexural Reinforced Concrete Members". Alexandria Engineering Journal, Vol. 51 (3) pp $211-220,2012$.

[20] Falade, F and Oyekan, G.L. "Bond strength of reinforced laterite concrete beams". 31st Conference on our World in Concrete \& Structures: 16 - 17 August, 2006.Singapore. 2006. 